\title{
Effect of Chromium Plating on the Plastic Deformation of SAE 4130 Steel
}

\author{
Hugh L. Logan
}

\begin{abstract}
The effects of chromium plating on the plastic deformation of SAE 4130 steel, hardness Rockwell C40, have been evaluated from the results of tensile, tensile impact, bending and crushing tests. Chromium plating materially reduces the percentage of elongation, true stress"at beginning of fracture, and the ratio of the original cross-sectional area to the area at beginning of fracture. Values of these properties decreased with increased plating thickness. Baking after plating generally increased the ductility of the plated steel. The tensile and yield strengths in tensile tests and the elongation and reduction in area of tensile impact tests were generally reduced less than 10 percent by chromium plating and were changed only 'slightly by baking after plating.
\end{abstract}

\section{Introduction}

Electrodeposited chromium has found wide application in machine elements. Because of its hardness and the ease with which it can be applied, manufacturers and maintenance shops have used it frequently for protecting softer metals from wear or for salvaging worn or undersized parts. These considerations led the Bureau of Aeronautics, Department of the Navy, to request and to give support to an investigation, at this Bureau, of the effects of chromium plating on the plastic deformation and fatigue properties of steels used in aircraft. The results of the fatigue investigation have been reported. ${ }^{1}$ The effects of chromium plating on the plastic deformation of SAE 4130 steel are reported in the present paper.

Tensile, tensile impact, bending and crushing tests were used in evaluating the effects of the chromium plating on the plastic deformation of the steel studied. It is the usual commercial practice to bake chromium plated steel articles at a temperature of about $200^{\circ} \mathrm{C}$. for several hours following plating. Hence, in this investigation specimens were tested as plated and after they had been plated and given various baking treatments.

\section{Materials}

The steel used consisted of one lot of SAE $4130 \mathrm{rod}$ $5 / 8$ in. in diameter, and one lot of SAE 4130 tubing, having an outside diameter of $1 \frac{1}{2}$ in. and a $1 / 8$-in. wall thickness. The compositions of this steel, as determined by chemical and spectrochemical analyses, are given in table 1 .

TABLE 1. Composition of steel

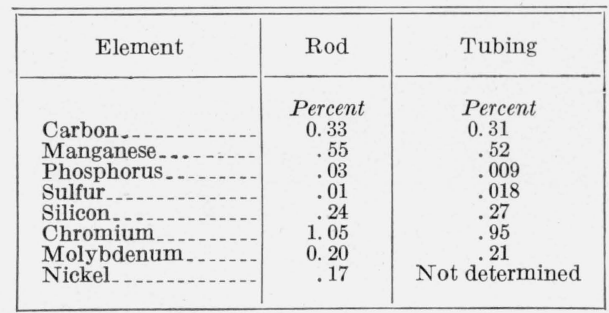

1 H. L. Logan. Effect of chromium plating on the endurance limit of steels used in aircraft, J. Research NBS 43, 101 (1949) RP2011; also ASTM Proc. 50 (1950).

\section{Specimens and Test Methods}

All specimens prepared from rod stock were rough machined, prior to heat treatment, to dimensions 0.015 to $0.020 \mathrm{in}$. greater than those of the finished specimens. These specimens and lengths of tubing for crushing tests were quenched from approximately $870^{\circ} \mathrm{C}$. into oil. All material was tempered for $1 \mathrm{hr}$. at $495^{\circ} \mathrm{C}$. and was then cooled in air. Following the heat treatment all specimens were machined to final dimensions.

Specimens of all types were tested as machined, after chromium plating to one or more thicknesses, and after plating and subsequent baking at various temperatures. Cleaning of specimens prior to plating has been described in an earlier paper. (See footnote 1.) Plating was carried out in an electrolyte containing $250 \mathrm{~g}$ /liter of $\mathrm{CrO}_{3}$ and $2.5 \mathrm{~g}$ /liter of $\mathrm{H}_{2} \mathrm{SO}_{4}$. The bath was maintained at $55^{\circ} \mathrm{C}$, and the current density was 350 amps/ $\mathrm{ft}^{2}$. The chromium plating thicknesses on the individual specimens were, in general, within \pm 25 percent of the nominal thicknesses given below.

Specimens were baked in an electrically heated laboratory oven, with forced air circulation, thermostatically controlled to $\pm 2 \operatorname{deg} \mathrm{C}$ at temperatures of $100^{\circ}$ and $200^{\circ} \mathrm{C}$. Temperatures of $300^{\circ}, 400^{\circ}$, and $440^{\circ} \mathrm{C}$, controlled to $\pm 3 \mathrm{deg} \mathrm{C}$, were obtained in an electrically heated tempering furnace with forced air circulation.

\section{Tensile Specimens}

The tensile specimens were machined with diameters in the reduced section of $0.4375 \pm 0.0010 \mathrm{in}$. and gage lengths of 2 in. Specimens were tested, (1) as machined, (2) after plating to nominal thicknesses of $0.0001,0.001,0.010$, and 0.015 in., and (3) after plating to above thicknesses and baking at various temperatures. The yield strength, tensile strength, and percentage of elongation in 2 in. were determined on each of the specimens. True stresstrue strain data were also obtained in the stress range extending from just above the yield strength to fracture on specimens as machined and with 


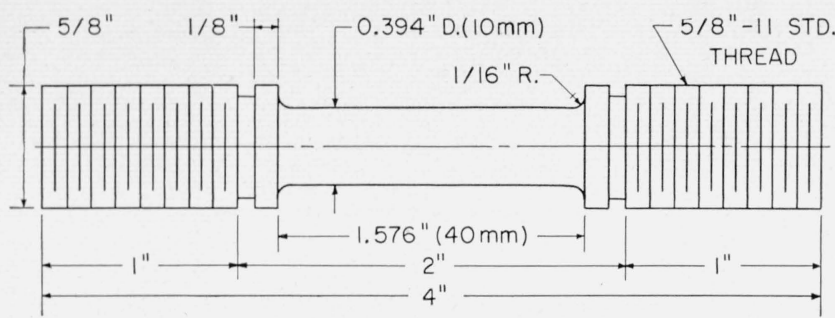

FIGURE 1. Specimen for tensile impact tests made in accordance with drawing prepared at the New York Naval Ship Yard.

plating thicknesses of $0.0001,0.001$, and 0.010 in., in the conditions as plated and as baked.

Yield strengths were determined at 0.2 percent offset from the modulus line from autographically recorded load-strain curves obtained with a Templin type high magnification extensometer. After the specimens had extended so that a yield load could be determined, the recording extensometer was removed. Diameters of these specimens on which true stress-strain data are reported were measured manually, to failure of the specimens, using a dial gage caliper reading to $0.001 \mathrm{in}$. All tensile properties were computed on the total diameters of the specimens, that is, diameter of the basis steel plus the thickness of chromium plating. True stressstrain data were obtained from simultaneous readings of the applied loads and the minimum diameters of the specimens; values for true strains were computed as the $\log _{e} A_{0} / A$, where $A_{0}$ and $A$ are the original (including plating) and current minimum areas of the cross sections of the specimens.

\section{Tensile Impact Specimens}

Tensile impact specimens were machined in accordance with the drawing shown in figure 1 . The specimens were tested at the New York Naval Ship Yard as machined, as plated to a nominal thickness of $0.015 \mathrm{in}$. and after plating and various baking treatments. The tests were conducted at room temperature, the striking velocity was $27.8 \mathrm{ft} / \mathrm{sec}$.

\section{Bend Test Specimens}

The rod material used for bend tests was cut into 10-in. lengths. These lengths were ground to a finished diameter prior to plating of $0.500 \pm 0.001 \mathrm{in}$. Specimens were chromium plated to a nominal thickness of $0.015 \mathrm{in}$. and were tested as plated and after various baking treatments. Bend tests were made in a hydraulic type testing machine, as shown in figure 2, at a free (unloaded) cross-head speed of 0.05 to $0.10 \mathrm{in} . / \mathrm{min}$. The load was applied until the specimen failed (usually with sudden fracture) or until the limitations of the apparatus (angle of bend bout $145^{\circ}$ ) prevented further bending.

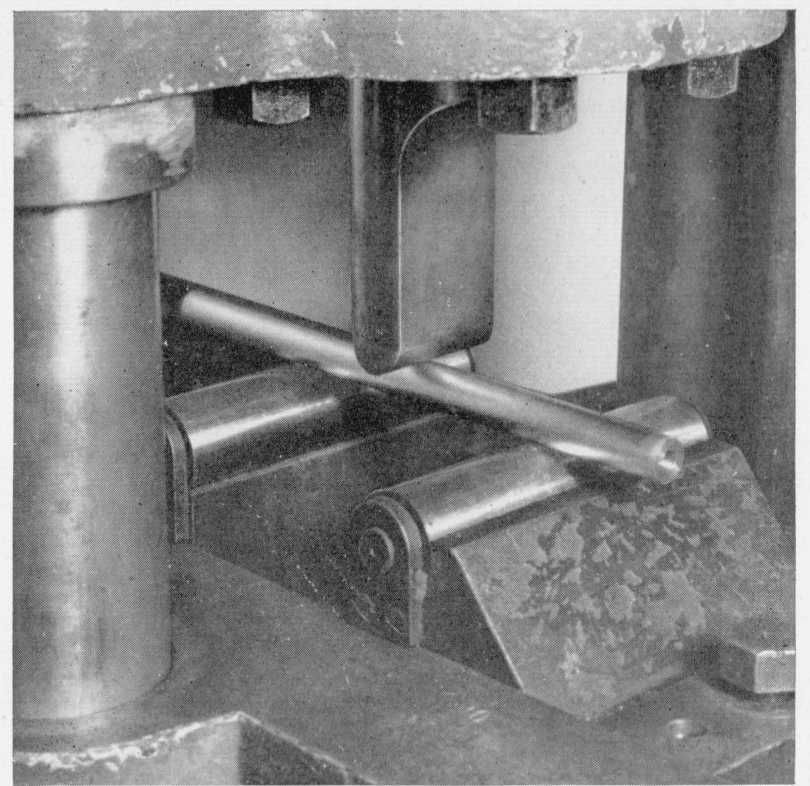

Figure 2. Chromium plated steel rod, in position for bend test. Supports were $10 \mathrm{~cm}$ apart.

\section{Crushing Test Specimens}

Specimens for crushing tests were prepared from the steel tubing by machining to an outside diameter, of $1.480 \pm 0.0005$ in., an inside diameter of $1.273 \pm$ $0.0005 \mathrm{in}$. and a wall thickness of $0.1033 \pm 0.0005 \mathrm{in}$. Specimens were $0.902 \pm 0.001$ in. long. Specimens were plated on both the inner and outer cylindrical surfaces to a nominal thickness of $0.010 \mathrm{in}$. They were tested to failure by compressing between parallel plates, the direction of the load being along a diameter of the tube. Tests were made in a hydraulic type testing machine at a free cross-head speed of 0.05 to $0.1 \mathrm{in} . / \mathrm{min}$. Failure of the specimen was indicated by a loud report and a sudden decrease in the load.

\section{Results and Discussion}

\section{Effect of Chromium-Plating on the Tensile Prop- erties of SAE 4130 Steel Specimens}

The results of tensile tests on unplated specimens are given in table 2; data on specimens plated to four thicknesses, as plated and after various baking treatments are given in table 3. Many of these data, plotted in percentage of values obtained for the unplated steel, are shown graphically in figure 3. True stress-true strain curves for the unplated steel and for specimens plated to nominal thicknesses of 0.0001 to 0.010 in., inclusive, are shown in figures 5 to 7 , inclusive. True stress-true strain curves for the unplated specimens heat treated alike but at different times (lots a, b and c, table 2) differed slightly in slope and are shown with the curves for plated steel for which they are applicable in figures 5,6 , and 7 . 
TABLE 2. Results of tensile tests on unplated SAE 4130 steel specimens

Data reported were obtained from 5 specimens of each group

\begin{tabular}{|c|c|c|c|c|c|c|c|c|c|c|}
\hline \multirow{2}{*}{ Lot a } & \multicolumn{2}{|c|}{ Yield strength } & \multicolumn{2}{|c|}{ Tensile strength } & \multicolumn{2}{|c|}{ Elongation in 2 in. } & \multicolumn{2}{|c|}{$\begin{array}{c}\text { True stress at begin- } \\
\text { ning of fracture }\end{array}$} & \multicolumn{2}{|c|}{$\begin{array}{l}\text { Original area of speci- } \\
\text { men/area at begin- } \\
\text { ning of fracture }\end{array}$} \\
\hline & A verage & $\begin{array}{l}\text { Standard } \\
\text { deviation b }\end{array}$ & Average & $\begin{array}{l}\text { Standard } \\
\text { deviation b }\end{array}$ & A verage & $\begin{array}{l}\text { Standard } \\
\text { deviation b }\end{array}$ & Average & $\begin{array}{l}\text { Standard } \\
\text { deviation b }\end{array}$ & A verage & $\begin{array}{c}\text { Standard } \\
\text { deviation b }\end{array}$ \\
\hline $\mathrm{a}_{\mathrm{a}}$ & $\begin{array}{l}\text { lb/in. } .^{2} \\
173,900 \\
175,900 \\
178,000\end{array}$ & $\begin{array}{l}\% \\
2.5 \\
0.3 \\
1.5\end{array}$ & $\begin{array}{l}l b / \text { in }^{2} \\
186,000 \\
187,300 \\
188,700\end{array}$ & $\begin{array}{l}\% \\
1.4 \\
0.4 \\
.7\end{array}$ & $\begin{array}{l}\% \\
12.5 \\
12.7 \\
13.4\end{array}$ & $\begin{array}{l}\% \\
10 \\
3.5 \\
1.7\end{array}$ & $\begin{array}{l}l b / \text { in. }^{2} \\
267,900 \\
273,900\end{array}$ & $\begin{array}{c}\% \\
2.3 \\
0.9\end{array}$ & $\begin{array}{l}2.069 \\
\text { 2. } 107\end{array}$ & $\begin{array}{l}\% \\
2.3 \\
1.6\end{array}$ \\
\hline
\end{tabular}

a Lots a, b, and c were heat treated at different times under approximately the same conditions.

b Standard deviations are reported in percentage of values for unplated steel specimens.

TABLE 3. Results of tensile tests on chromium plated SAE 4130 steel specimens

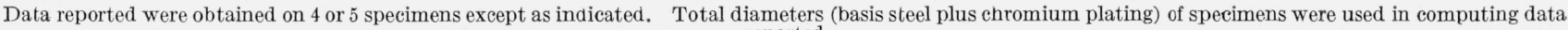
reported

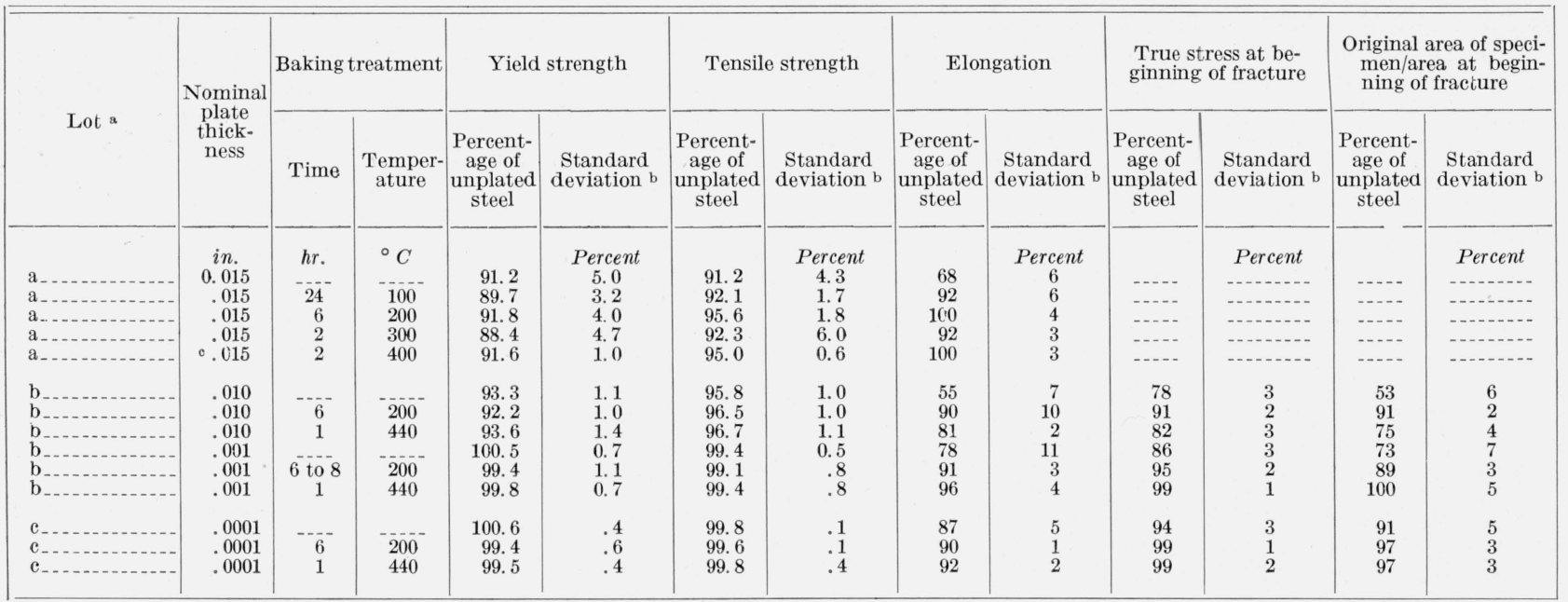

a Lots a, b, and c were heat treated at different times under approximately the same conditions.

b Standard deviations are reporied in percentage of the average values (of the properties) obtained on the unplated steel.

- Values reported were obtained on 3 specimens.

The effects of chromium plating on the tensile properties (of specimens tested as plated) were most noticeable in the reduction of values of (a) true stress (load/corresponding cross-sectional area) at beginning of fracture, (b) $A_{0} / A_{r}$ (original cross sectional area/ cross-sectional area at beginning of fracture), (c) percentage of elongation in 2 in., and (d) the flow stress at equal values of true strain. The properties listed (a), (b), and (c) and the true stress-true strain relationships indicate the ability of the material to withstand plastic deformation and will be referred to hereafter as deformation properties. The reduction in these deformation properties became greater as the plating thickness was increased from 0.0001 to 0.010 in.

The yield and tensile strengths of specimens decreased with plating thickness as the thickness became greater than 0.001 in., figure $3, \mathrm{~B}$ and $\mathrm{A}$, and were approximately 91 percent of that of the unplated steel for specimens plated to a thickness of $0.015 \mathrm{in}$. These data indicated that the tensile and yield strengths of the chromium plate were appreciably less than those of the basis steel.
Baking of plated specimens for 6 to $8 \mathrm{hr}$ at $200^{\circ} \mathrm{C}$, prior to testing, produced substantial increases in the deformation properties over results obtained on plated but unbaked specimens, as is shown in figure 3, C, D, and E. For specimens plated to thicknesses of 0.0001 and 0.001 in., baking at $440^{\circ} \mathrm{C}$ produced greater increases in values of these deformation properties than were obtained by baking at $200^{\circ} \mathrm{C}$. For specimens plated to a thickness of 0.010 in., some improvement was obtained in these properties by baking at $440^{\circ} \mathrm{C}$ for $1 \mathrm{hr}$, but this improvement was not as great as that obtained by baking at $200^{\circ} \mathrm{C}$ for $6 \mathrm{hr}$. Greater improvement in these deformation properties might have been obtained by baking specimens with the $0.010 \mathrm{in}$. thick plating for a longer period at $440^{\circ} \mathrm{C}$, preferably in an inert atmosphere or in a protective bath.

In general the yield and tensile strengths of the plated specimens were not appreciably changed by baking at $200^{\circ}$ or $440^{\circ} \mathrm{C}$, figure $3, \mathrm{~A}$ and $\mathrm{B}$. The apparent increase in the tensile strength of specimens plated to thicknesses of 0.015 in. and baked at $200^{\circ} \mathrm{C}$ was probably not significant. 

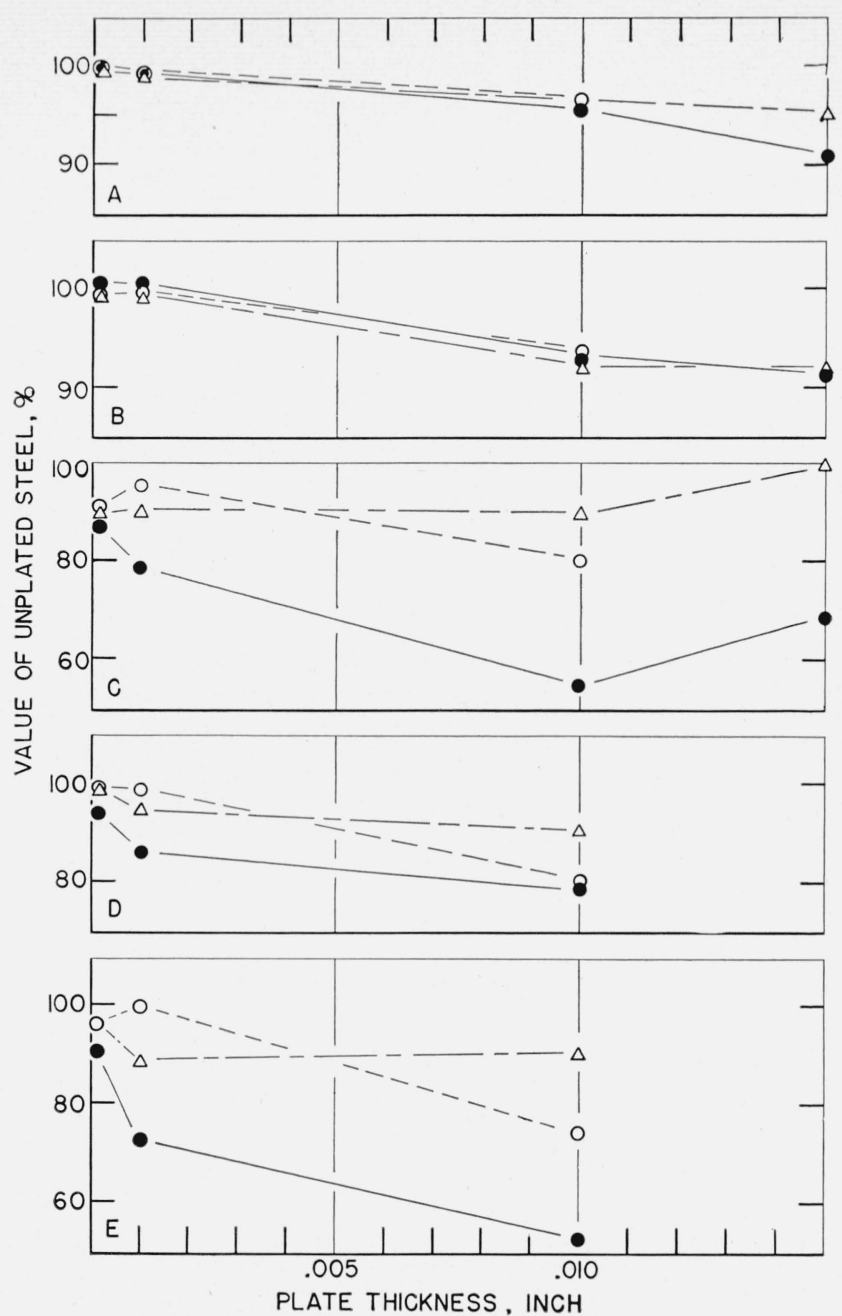

Figure 3. Relationship between $A$, tensile strength, $B$, yield strength, $C$, percentage of elongation, $D$, true stress at beginning of fracture, $E$, true strain at beginning of fracture and plate thickness of chromium plated SAE 4130 steel specimens.

-, As plated; $\triangle$, plated and baked 6 to $8 \mathrm{hr}$ at $200^{\circ} \mathrm{C}$; $\bigcirc$, plated and baked $1 \mathrm{hr}$ at $440^{\circ} \mathrm{C}$.

In making the tensile tests on the specimens plated to thicknesses of 0.010 in. or more it was noted that a part of the chromium spalled off the specimens just after the maximum load had been reached. During this part of the tests, loads and cross-sectional areas were changing extremely rapidly, and neither loads nor specimen diameters could be accurately determined; therefore the true stress-true strain curves are represented by broken lines in these regions (fig. 5).

Specimens from which part of the chromium had spalled are shown in figure 4. Measurements of the reduced sections of these specimens at the conclusion of the test and after the remaining chromium had been stripped from the steel indicated that about 0.003 to .0035 in. of chromium remained on specimens originally plated to a thickness of about 0.010 in. There was no appreciable spalling of chromium,

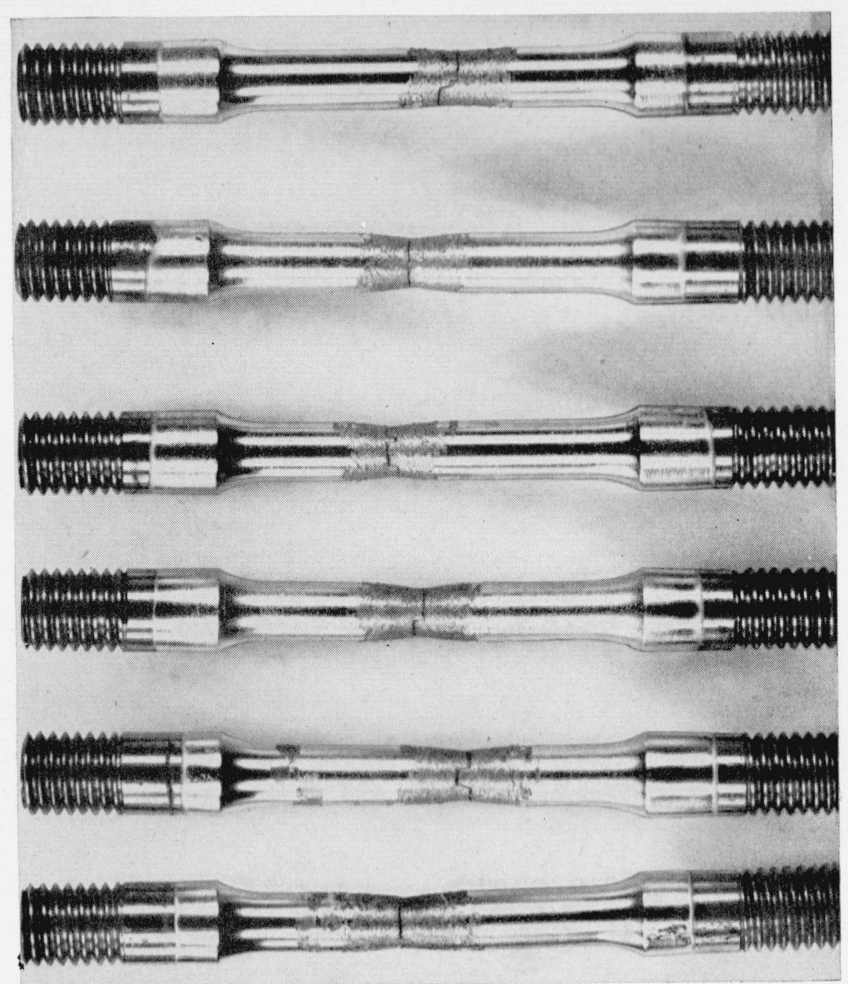

Figure 4. Specimens plated to a nominal thickness of $0.010 \mathrm{in}$. and broken without subsequent baking.

Note that a part of the chromium plating has spalled off from the reduced section.

during tests, from specimens plated to thicknesses of 0.001 and $0.0001 \mathrm{in}$.

True stress-true strain relationships plotted for specimens chromium plated to a nominal thickness of 0.010 in., figure 5, were well below that obtained for specimens of the unplated steel. There was a considerable amount of scatter in data obtained on all specimens plated to this thickness. The scatter in data for specimens plated and baked at $200^{\circ} \mathrm{C}$ was less than in that for specimens tested either as plated or after they had been plated and subsequently baked for $1 \mathrm{hr}$ at $440^{\circ} \mathrm{C}$.

True stress-true strain relationships for specimens plated to thicknesses of 0.001 and 0.0001 in. (figs. 6 and 7 ) were closer to those for the unplated steel than was the case for specimens plated to a thickness of $0.010 \mathrm{in}$. True stress-true strain relationships for specimens plated to nominal thicknesses of 0.001 and 0.0001 in. and subsequently baked at $200^{\circ} \mathrm{C}$, for 6 to $8 \mathrm{hr}$, approached those for the unplated steel much more closely than did the relationships for the unbaked specimens. Relationships for specimens baked for $1 \mathrm{hr}$ at $440^{\circ} \mathrm{C}$ approximately coincided with those for the unplated steel.

The electrodeposition of chromium is electrochemically a very inefficient operation. Only 15 to 20 percent of the current is effective in depositing chromium, and large quantities of hydrogen are re- 

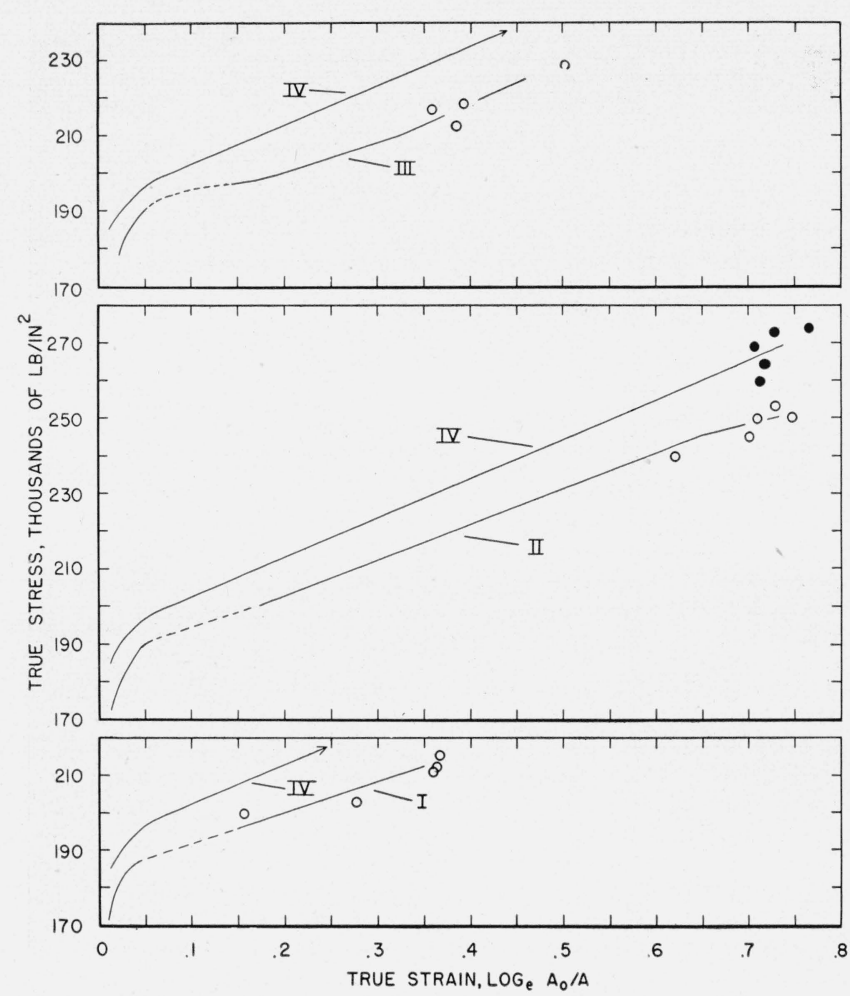

Figure 5. True stress-true strain curves for specimens plated to a nominal thickness of $0.010 \mathrm{in}$.

I, Specimens tested as plated; II, specimens plated and baked $6 \mathrm{hr}$ at $200^{\circ} \mathrm{C}$; III, specimens plated and baked $1 \mathrm{hr}$ at $440^{\circ} \mathrm{C}$; IV, unplated specimens tested without baking; $O$, beginning of fracture for individual plated specimens; beginning of fracture for unplated specimens. No data were available in broken sections of curves because of spalling of chromium.

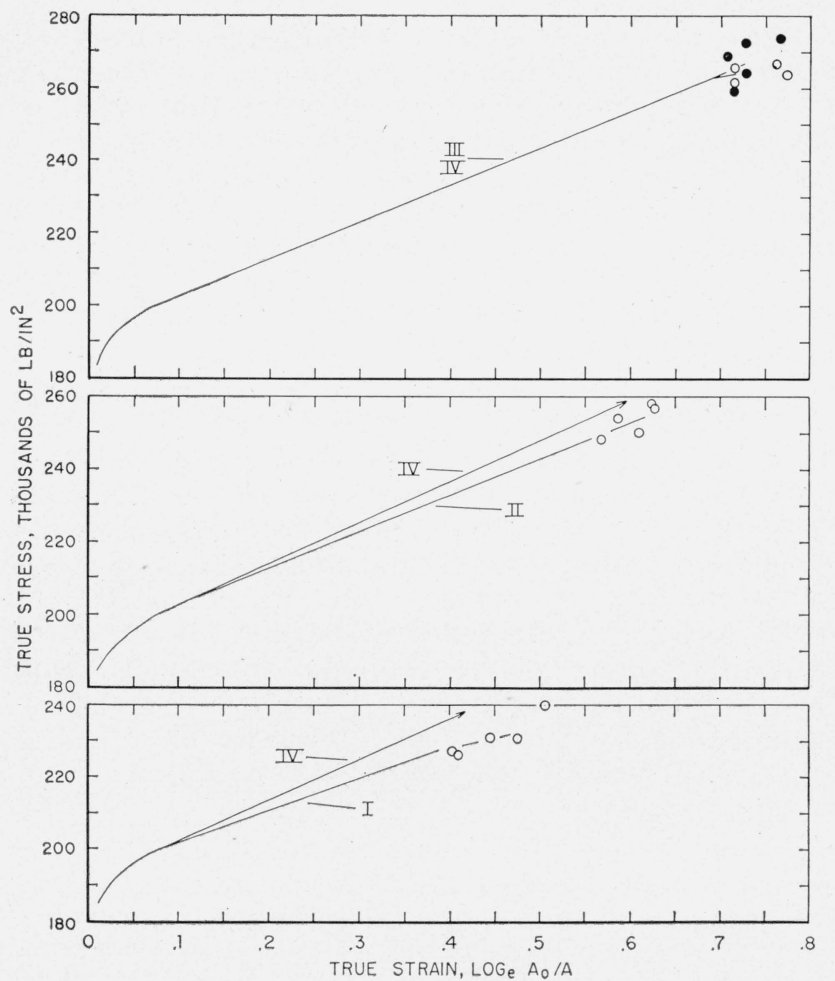

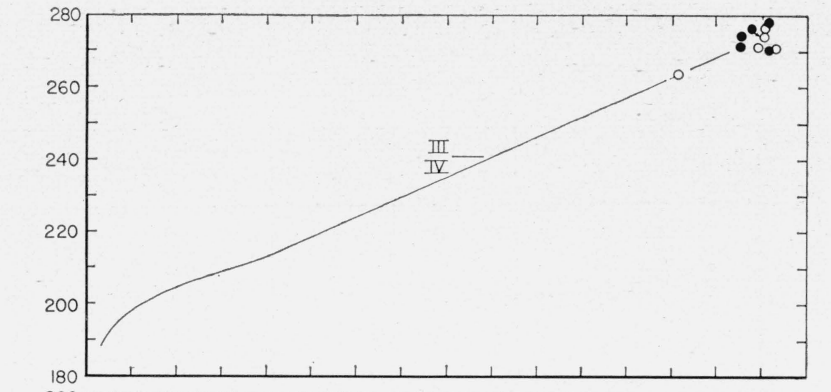
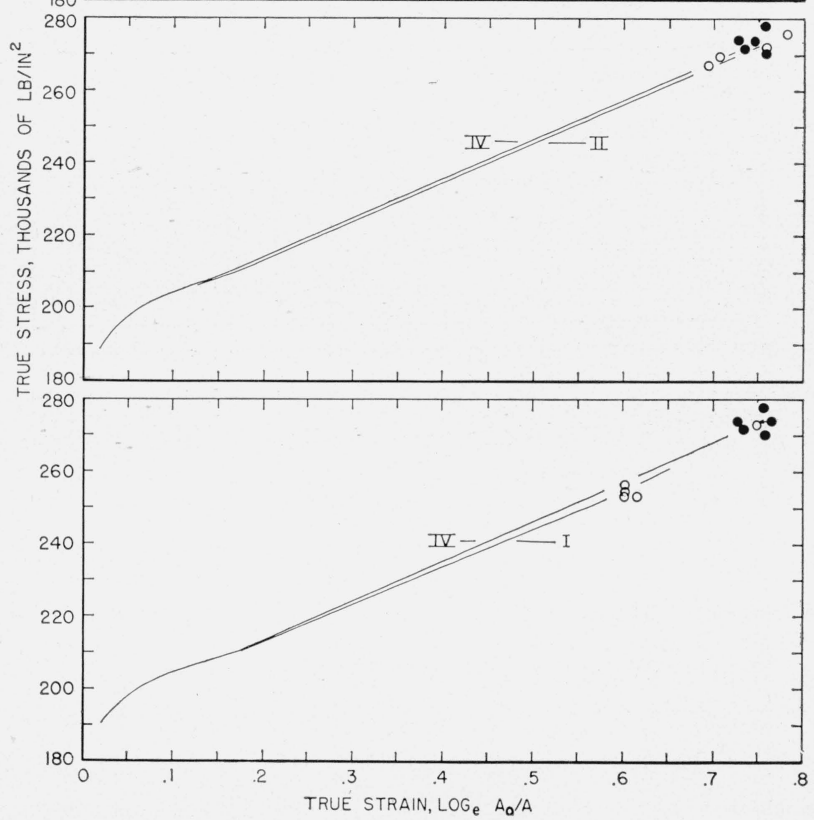

FiguRE 7. True stress-true strain curves for specimens plated to a nominal thickness of $0.0001 \mathrm{in}$.

I, Specimens tested as plated; II, specimens plated and baked $6 \mathrm{hr}$ at $200^{\circ} \mathrm{C}$; III, specimens plated and baked $1 \mathrm{hr}$ at $440^{\circ} \mathrm{C}$; IV, unplated specimens tested without baking; $O$, beginning of fracture for individual plated specimens; beginning of fracture for unplated specimens.

FIgure 6. True stress-true strain cuves for specimens plated to a nominal thickness of $0.001 \mathrm{in}$.

I, Specimens tested as plated; II, specimens plated and baked 6 to $8 \mathrm{hr}$ at $200^{\circ} \mathrm{C}$; III, specimens plated and baked $1 \mathrm{hr}$ at $440^{\circ} \mathrm{C}$; IV, unplated specimens teste without baking; $O$, beginning of fracture for individual plated specimens; beginning of fracture for unplated specimens. 


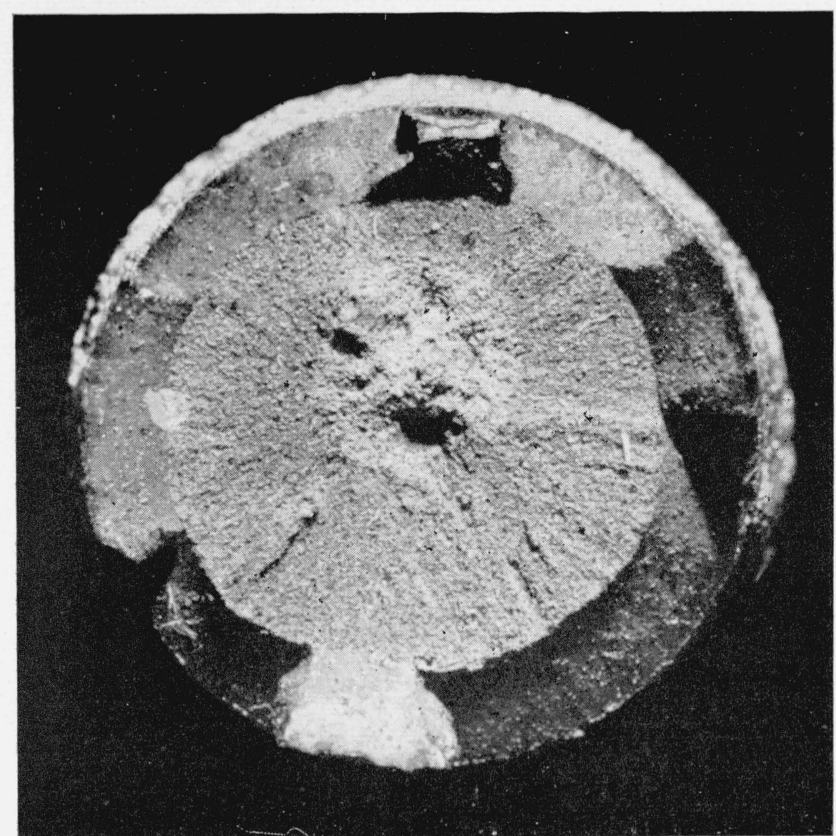

FIGURE 8. End of fractured specimen showing central spot differing in appearance from remaining area; $\times 8$.

leased at the cathode. It has been reported ${ }^{2}$ that 1 volume of chromium contains as much as 128 volumes of hydrogen. It is generally considered that hydrogen produces embrittlement in steel. In the present investigation atomic hydrogen was deposited on unplated tensile specimens by making them the cathodes in a 10 -percent $\mathrm{H}_{2} \mathrm{SO}_{4}$ solution. Specimens on which tests were begun approximately 1 min after they had been removed from the bath broke before yield loads $(0.2-\%$ off set from the modulus line) were reached. The elapsed time from the removal of the specimens from the bath to their fracture was 6 to $8 \mathrm{~min}$. Testing of one specimen was delayed for 5 to 6 min after it was removed from the solution and a true stress-true strain curve very similar to that of specimens tested as machined was obtained. These results indicate that the effects of depositing atomic hydrogen on a steel specimen are very transient. It is difficult to see how hydrogen, deposited on the steel during the chromium plating process, would be retained unless there was diffusion from the chromium into the steel and a state of equilibrium was set up. If such a condition existed, baking of specimens at $200^{\circ} \mathrm{C}$, which is reported ${ }^{3}$ to expel approximately half of the hydrogen from the chromium, would be expected to decrease the hydrogen in the steel and hence increase the plastic deformation prior to fracture. Baking at $440^{\circ} \mathrm{C}$ if continued for a sufficiently long period should remove more than 90 percent of the hydrogen from the

\footnotetext{
2 E. V. Potter and H. C. Lukens, Hydrogen content of electrolytic chromium and its removal, Metals Tech. 15 (Jan. 1948) T. P. 2312.

3 A. Brenner, P. Burkhead, and C. Jennings, Physical properties of electrodeposited chromium, J. Research NBS 40, 31 (1948) RP1854.
}

chromium and might be expected to further increase the plastic deformation that could occur in the basis steel before fracture occurred.

Tensile specimens plated to a nominal thickness of 0.010 in. and broken without subsequent baking showed areas near the center of the fractures that differed markedly in appearance from that of the remainder of the fractured surface. A typical area of this type is shown in figure 8. No markings of this type were found in specimens that had been baked before testing nor in specimens with thinner chromium plating nor in specimens loaded cathodically with hydrogen. No satisfactory explanation for the occurrence of these markings has as yet been proposed.

\section{Tensile Impact Tests}

Tensile impact tests were made at room temperature on specimens as machined, after plating to a thickness of approximately 0.015 in. and after plating to this thickness and baking for periods of $24 \mathrm{hr}$ at $100^{\circ} \mathrm{C}, 6 \mathrm{hr}$ at $200^{\circ} \mathrm{C}$, and 1 and $2 \mathrm{hr}$ at $300^{\circ} \mathrm{C}$. The results are given in table 4 . The data indicate that chromium plating slightly reduced the energy absorbed by the specimens and also the ductility as measured both by percentage of elongation and reduction in area. Baking of plated specimens at temperatures up to $300^{\circ} \mathrm{C}$ produced no significant changes in these properties of the plated specimens. No data were obtained on specimens heated at temperatures above $300^{\circ} \mathrm{C}$.

Seabrook, Grant, and Carney ${ }^{4}$ have shown that the effects of hydrogen embrittlement decreased with increased strain rates. The results obtained in the tensile impact tests and tensile tests are in agreement with their conclusions if the reductions in plastic deformation of the steels under test are due to hydrogen embrittlement.

\section{Bend Tests}

Bend tests were made on specimens as machined, after plating to a thickness of about 0.015 in. and after plating and baking for periods of $24 \mathrm{hr}$ at $100^{\circ}$ $\mathrm{C}, 16 \mathrm{hr}$ at $200^{\circ} \mathrm{C}, 7 \frac{3}{4} \mathrm{hr}$ at $300^{\circ} \mathrm{C}$, and $1 \mathrm{hr}$ at $440^{\circ} \mathrm{C}$. The data are given in table 5. The applied loads reached maximum values while the angles of bend $\left(180^{\circ}\right.$ minus the angle included between the two legs of the specimen) were still small and thereafter decreased until the specimens failed or until the limitations of the apparatus prevented further bending. It was noted that unplated specimens were bent through an angle of about $145^{\circ}$ without failure. Plated specimens failed after they had been bent through angles of approximately $40^{\circ}$. Specimens plated and then baked before testing could be bent through angles of $70^{\circ}$ to $80^{\circ}$ before failure occurred. Specimens plated and subsequently baked at $200^{\circ} \mathrm{C}$ or some higher temperature had

4 J. B. Seabrook, N. J. Grant, and D. J. Carney, Hydrogen embrittlement of SAE 1020 steel. J. Metals 188, 1317 (1950). 
TABLE 4. Results of tensile impact tests on SAE 4130 steel specimens chromium plated to a nominal thickness of 0.015 in.

\begin{tabular}{|c|c|c|c|c|c|c|c|c|}
\hline \multirow{2}{*}{$\begin{array}{l}\text { Number of speci- } \\
\text { mens tested }\end{array}$} & \multicolumn{2}{|c|}{ Baking treatment } & \multicolumn{2}{|c|}{ Total energy } & \multicolumn{2}{|c|}{ Elongation } & \multicolumn{2}{|c|}{ Reduction in area } \\
\hline & Time & Temperature & A verage & $\begin{array}{c}\text { Standard } \\
\text { deviation }\end{array}$ & A verage & $\begin{array}{l}\text { Standard } \\
\text { deviation }\end{array}$ & Average & $\begin{array}{l}\text { Standard } \\
\text { deviation }\end{array}$ \\
\hline $\begin{array}{l}3 \\
3 \\
3 \\
6 \\
6 \\
6 \\
6 \\
3\end{array}$ & \begin{tabular}{l}
\multicolumn{1}{c}{$h r$} \\
Not plated \\
Plated, not baked. \\
24 \\
6
\end{tabular} & $\begin{array}{l}\quad{ }^{\circ} C \\
\text { Not plated } \\
\text { Plated, not baked. } \\
100 \\
200\end{array}$ & $\begin{array}{c}f t-l b \\
464 \\
431 \\
435 \\
425 \\
408 \\
416\end{array}$ & $\begin{array}{c}f t-l b \\
27 \\
19 \\
14 \\
23 \\
50 \\
44\end{array}$ & $\begin{array}{c}\text { Percent } \\
15.8 \\
14.9 \\
15.0 \\
14.4 \\
14.1 \\
14.5\end{array}$ & $\begin{array}{c}\text { Percent } \\
0.4 \\
.4 \\
.8 \\
1.2 \\
1.7 \\
1.0\end{array}$ & $\begin{array}{l}\text { Percent } \\
55.2 \\
53.6 \\
54.2 \\
51.2 \\
52.4 \\
50.1\end{array}$ & $\begin{array}{c}\text { Percent } \\
0.8 \\
.8 \\
1.6 \\
2.1 \\
2.1 \\
2.5\end{array}$ \\
\hline
\end{tabular}

approximately the same moduli of rupture [(9.975) maximum load $/(\text { diameter of specimen })^{3}$ ] computed on the total diameters of the specimens, as the unplated steel.

TABLE 5. Results of bend tests on chromium plated SAE 4130 steel rod $0.500 \mathrm{in}$. in diameter plated to a nominal thickness of $0.015 \mathrm{in}$.

\begin{tabular}{|c|c|c|c|c|c|c|c|}
\hline \multicolumn{2}{|c|}{ Baking treatment } & \multicolumn{2}{|c|}{$\begin{array}{l}\text { Angle of bend } \\
\text { at failure }\end{array}$} & \multicolumn{2}{|c|}{$\begin{array}{l}\text { Maximum } \\
\text { load }\end{array}$} & \multicolumn{2}{|c|}{$\begin{array}{l}\text { Modulus of } \\
\text { rupture }\end{array}$} \\
\hline Time & $\begin{array}{l}\text { Temper- } \\
\text { ature }\end{array}$ & $\begin{array}{l}\text { Aver- } \\
\text { age }\end{array}$ & $\begin{array}{l}\text { Stand- } \\
\text { ard } \\
\text { devia- } \\
\text { tion }\end{array}$ & $\begin{array}{l}\text { Aver- } \\
\text { age }\end{array}$ & $\begin{array}{l}\text { Stand- } \\
\text { ard } \\
\text { devia- } \\
\text { tion }\end{array}$ & $\begin{array}{l}\text { Aver- } \\
\text { age }\end{array}$ & $\begin{array}{l}\text { Stand- } \\
\text { ard } \\
\text { devia- } \\
\text { tion }\end{array}$ \\
\hline $\begin{array}{c}h r \\
\begin{array}{c}\text { Unplated } \\
\text { plated, not } \\
\text { baked. }\end{array} \\
16 \\
73 / 4\end{array}$ & 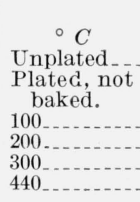 & $\begin{array}{c}\text { Degrees } \\
\text { a } 146 \\
42 \\
\\
79 \\
84 \\
71 \\
82\end{array}$ & $\begin{array}{c}\text { Degrees } \\
1 \\
7 \\
\\
13 \\
4 \\
5 \\
8\end{array}$ & $\begin{array}{c}L b \\
5,350 \\
6,020 \\
6,130 \\
6,370 \\
6,540 \\
6,330\end{array}$ & $\begin{array}{r}L b \\
0 \\
80 \\
\\
105 \\
105 \\
160 \\
60\end{array}$ & $\begin{array}{c}1,000 \\
\text { lb/in. }{ }^{2} \\
425 \\
400 \\
\\
400 \\
430 \\
415 \\
425\end{array}$ & $\begin{array}{c}1,000 \\
\text { lb/in. }{ }^{2} \\
2 \\
3 \\
\\
13 \\
8 \\
25 \\
3\end{array}$ \\
\hline
\end{tabular}

a Specimens đid not break.

Spalling of chromium from the steel usually began before the maximum load was reached; all or nearly all of the chromium had spalled from some of the specimens, in the region of maximum deformation, before failure occurred.

\section{Crushing Tests on Tubing}

Crushing tests were made on tubes 1.480 in. in outside diameter by 0.902 in. long with a 0.1033 -in. wall thickness. Specimens were tested as machined, after plating on the inside and outside surfaces to a thickness of about $0.010 \mathrm{in}$. and after plating and baking for periods of $8 \mathrm{hrs}$ at $100^{\circ} \mathrm{C}, 6 \mathrm{hrs}$ at $200^{\circ} \mathrm{C}$, $1 \mathrm{hr}$ at $300^{\circ} \mathrm{C}$, and $1 \mathrm{hr}$ at $400^{\circ} \mathrm{C}$. The data are given in table 6 . It was noted that plating increased the load necessary to crush the specimen and reduce the deformation at failure to about 9 percent of that of the unplated steel. Baking of plated specimens increased both the breaking load and the deformation at fracture. After baking the specimens for $6 \mathrm{hrs}$ at $200^{\circ} \mathrm{C}$, the average load required to break the specimens was approximately 1.4 times that required to crush the unplated specimens; however, the deformation was only about 55 percent of that of the unplated steel. Typical specimens that had failed in the test are shown in figure 9 .
TABLE 6. Results of crushing tests on chromium plated $S A E$ 4130 steel tubing, $1.480 \mathrm{in}$. in diameter by $0.902 \mathrm{in}$. long with $0.1033 \pm 0.0005$ in. wall thickness

\begin{tabular}{|c|c|c|c|c|c|}
\hline \multicolumn{2}{|c|}{ Baking treatment } & \multicolumn{2}{|c|}{ Breaking load } & \multicolumn{2}{|c|}{ Deformation a } \\
\hline Time & Temperature & A verage & $\begin{array}{l}\text { Stand- } \\
\text { ard } \\
\text { devia- } \\
\text { tion }\end{array}$ & A verage & $\begin{array}{l}\text { Stand- } \\
\text { ard } \\
\text { devia- } \\
\text { tion }\end{array}$ \\
\hline $\begin{array}{l}\text { Hours } \\
\text { Not plated }\end{array}$ & $\stackrel{\circ}{\circ}$ & $\begin{array}{c}L b \\
2,990\end{array}$ & $\begin{array}{c}L b \\
90\end{array}$ & $\begin{array}{l}\text { in. } \\
0.2025\end{array}$ & $\begin{array}{l}\text { in. } \\
0.091\end{array}$ \\
\hline $\begin{array}{l}\text { Plated, not } \\
\text { baked. }\end{array}$ & $\begin{array}{l}\text { Plated, not } \\
\text { baked. }\end{array}$ & 3,650 & 330 & .0180 & .010 \\
\hline & 100 & 4,045 & 90 & .0610 & .008 \\
\hline & 200 & 4,285 & 45 & .1110 & .010 \\
\hline & & 4,285 & 160 & .1115 & .012 \\
\hline & 400 & 4,155 & 125 & .1090 & .013 \\
\hline
\end{tabular}

a Deformation is original diameter of plated specimen minus minor diameter of specimen after failure.

\section{Summary}

1. The effects of chromium plating on certain mechanical properties of SAE 4130 steel were determined from tensile, tensile impact, bend and crushing tests. Data were obtained on specimens as plated and after baking at various temperatures.

2. The most noticeable effect of chromium plating was to appreciably reduce the plastic deformation prior to fracture in all types of test except the tensile impact. The reduction of elongations in tensile tests was particularly noticeable.

3. Tensile and yield strengths of plated specimens decreased as the plate thickness was increased from 0.001 to 0.015 in. However, these properties determined on specimens plated to a thickness of 0.015 in. were 91 percent or more of the corresponding properties of the unplated steel.

4. The plastic deformation prior to fracture, in the tensile tests, became less as the plating thickness was increased.

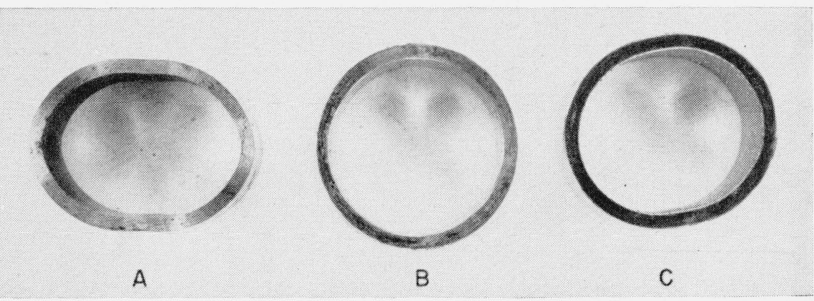

Figure 9. Tube specimens that had failed in the crushing test. A, Unplated specimen; B, plated specimen tested without subsequent baking $\mathrm{C}$, specimen plated and baked at $200^{\circ} \mathrm{C}$ prior to testing. 
5. Baking of chromium plated steel specimens at temperatures of $100^{\circ}$ to $440^{\circ} \mathrm{C}$ for various periods increased the plastic deformation that could be produced in the plated steel above that obtained on specimens tested as plated. The tensile and yield strengths of the plated specimens were not appreciably changed by the baking treatments.

6 . It is suggested that hydrogen deposited on the steel with the chromium may be a factor in reducing the amount of plastic deformation that the steel can withstand prior to fracture.
Specimens used in this investigation were plated by personnel of the Bureau's Electrodeposition Section under the direction of W. Blum and Vernon Lamb. Tension impact tests were made by personnel of the New York Naval Ship Yard, Brooklyn, N. Y. The following members of the staff of the Bureau's Metallurgy Division have given valuable assistance in the experimental work reported in this paper, Harold Hessing, Houston Babb, and Thomas P. Royston, Jr.

Washington, October 30, 1950. 